\title{
Downregulation of ABCA1 and ABCG1 transporters by simvastatin in cholangiocarcinoma cells
}

\author{
PATTAYA SEEREE ${ }^{1}$, TAVAN JANVILISRI ${ }^{2}$, THANED KANGSAMAKSIN ${ }^{2}$, \\ RUTAIWAN TOHTONG ${ }^{2}$ and SUPEECHA KUMKATE ${ }^{1}$
}

Departments of ${ }^{1}$ Biology and ${ }^{2}$ Biochemistry, Faculty of Science, Mahidol University, Bangkok 10400, Thailand

Received March 15, 2019; Accepted August 13, 2019

DOI: $10.3892 / \mathrm{ol} .2019 .10874$

\begin{abstract}
Disturbances in cholesterol homeostasis of the bile duct epithelium, including transport interruption and the hyperaccumulation of intracellular cholesterol can lead to the initiation and progression of cholangiocarcinoma (CCA). Statins, which are lipid-lowering drugs, have been previously documented to exhibit anti-cancer properties. The role of statins in CCA cell cholesterol transport through the expression and function of ATP-binding cassette (ABC) A1 and ABCG1 was investigated in the current study. In four CCA cell lines, ABCA1 and ABCG1 expression was identified. However, neither ABCG5 nor ABCG8 expression was observed. Immunocytochemistry revealed that the expression of ABCA1 was localized in the proximity of the nucleus, while ABCG1 was more dispersed throughout the cytoplasm of KKU-100 cells. A cholesterol efflux assay was performed using bodipy cholesterol, and the translocation of cholesterol via ABCA1 and ABCG1 to Apo-A1 and high density lipoprotein was confirmed, respectively. Simvastatin and atorvastatin demonstrated the inhibitory effects on CCA cell viability. A reduction in intracellular lipid level and a lower expression of ABCA1 and ABCG1 were observed in KKU-100 cells under simvastatin treatment. The pre-exposure of KKU-100 cells to cholesterol diminished the statin effect. Furthermore, when KKU-100 cells were pre-loaded with cholesterol, ABCA1 and ABCG1-mediated exports were unaffected even though they were treated with simvastatin. The results of the current study indicated the limitations of the use of statin in CCA therapy, particularly under hypercholesterolemia conditions.
\end{abstract}

Correspondence to: Dr Supeecha Kumkate, Department of Biology, Faculty of Science, Mahidol University, 272 Rama 6 Road, Ratchathewi, Bangkok 10400, Thailand

E-mail: supeecha.kum@mahidol.edu

Key words: statin, cholangiocarcinoma, ATP-binding cassette A1, ATP-binding cassette G1, cholesterol

\section{Introduction}

Cholangiocarcinoma (CCA) is a primary adenocarcinoma and malignancy arising from the epithelium of the bile duct. CCA can be classified by its origin into intrahepatic, perihilar, and distal CCA. The pathogenesis of CCA is poorly understood and needs further investigation. Furthermore, the incidence and mortality rate of CCA has increased worldwide over past decades and now accounts for $3 \%$ of all gastrointestinal malignancies (1). It is also highly prevalent in Southeast Asia particularly in Thailand due to the endemic parasitic biliary tract infestation (2). Lack of effective biomarkers makes early diagnosis of CCA difficult (3). The occurrence of symptoms may not be apparent until the cancer reaches an advanced stage resulting in severe outcomes (4). Previous studies have reported the association of chronic liver diseases, hepatolithiasis, chronic biliary inflammation and cholestasis with the development of CCA (3). Under liver inflammation, accumulation of cholesterol was observed and caused extreme damage to the cells (5). This indicates that cholesterol plays a significant role in liver diseases.

Bile consisting of cholesterol, phospholipids, bilirubin conjugates, bile salts and toxic substances is secreted from hepatocytes and passes along bile duct through gallbladder or small intestine. Excess cholesterols are excreted via bile and eliminated into feces (6). Some of cholesterols and unconjugated bile acids can passively diffuse into cholangiocytes (7). Cholangiocytes have important roles in modifying and delivering the bile to its destination by secreting bicarbonate and water thus, preventing bile acid diffusion and maintaining osmolality of the cell (7). At the same time, cholangiocytes maintain their cholesterol homeostasis and form junction preventing the hepatic interstitial tissue from these secreted toxic substances and bile (6). When the cholestasis occurred by the bile duct obstruction, this led to overexposure of cholangiocytes to bile lipid contents and toxic substances (8). Oxysterols are found to be increased in bile acids of patients with biliary tract inflammation. They are cholesterol oxidation derivatives in human bile and activators of the hedgehog signaling pathway which associates in cell proliferation, migration, and invasion of CCA $(9,10)$.

Cholesterol transport is a crucial cellular homeostatic mechanism. ATP-binding cassette (ABC) A1 and ABCG1 are well characterized as cholesterol transporters in various cell 
types (11-14). ABCA1 transports cholesterol and phospholipids to apolipoprotein A-1 (ApoA-1) while ABCG1 transports cholesterol to mature high density lipoprotein (HDL). In this context, ABCA1 malfunction is associated with atherosclerosis. Cholesterol accumulation causes a decrease in ABCA1 level enhancing intracellular cholesterol excess in macrophages. This leads to inflammation and cell apoptosis which eventually resulting in atherosclerosis (15). Furthermore, ABCA1 function is disrupted by epigenetic alteration of promoter hypermethylation in prostate cancer. Decrease in ABCA1 export ability enhances accumulation of intracellular cholesterol. Extended cholesterol pools are consistent with prostate cancer progression and aggressiveness (16). This underlines the importance of ABCA1 and cholesterol in diseases and cancers.

Statins, 3-hydroxy-3-methyl glutaryl coenzyme A (HMG-CoA) reductase inhibitors, are well-known for their LDL cholesterol lowering effects. $\mathrm{HMG}-\mathrm{CoA}$ reductase is involved in cholesterol synthesis reducing $\mathrm{HMG}-\mathrm{CoA}$ to mevalonate which is eventually converted into cholesterol. Statins primarily inhibit this process thus lowering cholesterol synthesis to balance cholesterol homeostasis (17). Multiple effects of statins in anti-proliferation and promotion of apoptosis are found to be useful in reducing risk of CCA cancer $(18,19)$. For instance, statins diminished insulin-like growth factor 1 (IGF-1) leading to the reduction of CCA cell proliferation (20). Statins also caused anti-proliferation and enhanced cell apoptosis by cell cycle arrest at sub G1 fraction in CCA (19). Further studies also revealed that simvastatin down-regulated serine/threonine kinase protein kinase B (Akt). Signalling through Akt plays a prominent role in several cancer types including prostate cancer (21), glioblastoma (22) and CCA (20). In addition, signaling through Akt pathway regulates ABCA1 transporter in pancreatic beta cells (23). Inhibition in Akt subsequently decreased ABCA1 expression and enhanced cholesterol efflux to Apo-A1 during autophagy which caused lipid raft imbalance in hepatocytes and macrophages (24).

In this study, the role of statins in the expression and function of major cholesterol transporters, ABCA1 and ABCG1 in CCA cells was investigated. Also, the involvement of Akt pathway in regulation of these transporters was examined. A specific condition of pre-exposure of CCA cells to cholesterol was also set to evaluate the effects of statins on ABCA1 and ABCG1-mediated efflux and its contribution to CCA survival and progression.

\section{Materials and methods}

Cell cultures. CCA cell lines including KKU-100 (JCRB no.1568), KKU-M213 (JCRB no. 1557) (25), HuCCA-1 (JCRB no. 1657) (26) were obtained from JCRB cell bank. RMCCA-1 cell line was cultured in our laboratory (Pubmed 17072981) (27) and HepG2 cells (ATCC no. 8065) were used to represent liver cancer cells. They were maintained in HAM's F12 (Invitrogen; Thermo Fisher Scientific, Inc.) and DMEM (Invitrogen) containing 10\% fetal bovine serum (FBS) (Sigma-Aldrich; Merck KGaA), $0.1 \mathrm{U} / 1$ penicillin and $0.1 \mathrm{~g} / 1$ streptomycin (Invitrogen) at $37^{\circ} \mathrm{C}$ in a $5 \% \mathrm{CO}_{2}$ incubator.

Preparation of statins and cholesterol. Simvastatin and atorvastatin (both from Santa Cruz Biotechnology, Inc.) were dissolved in DMSO (Sigma-Aldrich; Merck KGaA) and dilutions were made for appropriate treatment conditions at $1 \%$ final concentration of DMSO. Cholesterol (Santa Cruz Biotechnology, Inc.) was dissolved in chloroform and a desired concentration of cholesterol was left after being evaporated using nitrogen gas. The cholesterol was then resuspended in methyl- $\beta$-cyclodextrin (MCD; Sigma-Aldrich; Merck KGaA) at a ratio of 1:4.

Clonogenic survival assay. KKU-100 cells were seeded at 700 cells per well in a 6 -well plate and incubated for $24 \mathrm{~h}$. Cells were subjected to cholesterol loading for $1 \mathrm{~h}$ and statin treatment for $48 \mathrm{~h}$. They were allowed to grow into colonies for 14 days in a complete medium. Cells were then fixed with $4 \%$ paraformaldehyde, stained with crystal violet to examine their colony forming ability. Images of colonies were taken. Crystal formation was dissolved with glacial acetic acid before reading at $540 \mathrm{~nm}$ using an Infinite M200 PRO microplate reader (Tecan). The optimal statin and cholesterol concentrations were determined from cell viability curve. In subsequent assays, simvastatin at $25-50 \mu \mathrm{M}$ and cholesterol at $10 \mu \mathrm{M}$ were used, $1 \%$ DMSO in medium and/or MCD was added in a non-treated control cells.

Oil Red $O$ staining. After statin and cholesterol treatment, KKU-100 cells were fixed with $4 \%$ paraformaldehyde, stained with $0.5 \%$ oil red o (Santa Cruz Biotechnology, Inc.) and images were taken using an inverted light microscope (Eclipse TS100; Nikon).

RNA isolation and gene expression analysis by RT-PCR. Total RNA isolation was performed using RNeasy plus mini kit (Qiagen) according to the manufacturer's instructions. Total RNA concentration was determined by measuring a ratio of 260/280 nm absorbance using NanoVue (GE Healthcare Life Sciences). First strand complementary DNA (cDNA) was created from $1 \mu \mathrm{g}$ total RNA template using RevertAidReverse Transcriptase (Thermo Fisher Scientific, Inc.) according to manufacturer's instructions. One-hundred ng of cDNA was amplified using specific primers and Taq DNA (Vivantis). cDNA was used as a template in PCR analysis to measure the relative expression of $A B C A 1, A B C G 1, A B C G 5$, and $A B C G 8$ mRNA. The nucleotide sequences of the primers were as follows: hABCA1 (NM_005502.3), hABCA1-F GACGCA AACACAAAAGTGGA, hABCA1-R AACAAGCCATGT TCCCTCAG; hABCG1 (NM_207628.1), hABCG1-F CAG GGACCTTTCCTATTCGG, hABCG1-R GGCCACCAACTC ACCACTAT; hABCG5 (NM_022436.2), hABCG5-F GGC AGATCATGTGCATCCTA, hABCG5-R ACATACACCTCC CCCAGGAA; hABCG8 (NM_022437.2) hABCG8-F ATT TCACAGCCATCGGCTAC, hABCG8-R CGAGTGACT GAGCCTTCTCC; $h \beta$-actin (NM_001101.4), h $\beta$-actin-F GCA CAGAGCCTCGCCTT, h $\beta$-actin-R CTTTGCACATGCCGG AG. PCR products were amplified $\left(95^{\circ} \mathrm{C}, 1 \mathrm{~min}\right.$; followed by 40 cycles of $95^{\circ} \mathrm{C}, 45 \mathrm{sec}$, and $\left.58^{\circ} \mathrm{C}, 45 \mathrm{sec} ; 72^{\circ} \mathrm{C}, 45 \mathrm{sec}\right)$ and analyzed on a MC Nexus Gradient PCR cycler (Eppendorf AG). PCR products were loaded onto $2 \%$ agarose gel and stained with ethidium bromide. The sequences of the fragments amplified by PCR were confirmed by DNA sequencing. Semi-quantitative mRNA expression of $A B C A 1, A B C G 1$, 
$A B C G 5$, and $A B C G 8$ was normalized to $\beta$-actin mRNA levels using ImageJ program (Version 1.48) to calculate band intensity.

RNA isolation and gene expression analysis by $q P C R$. Total RNA isolation was conducted and cDNA was created from $1 \mu \mathrm{g}$ total RNA template as above. A total of $100 \mathrm{ng}$ of cDNA was amplified using above specific primers and SYBR Green real-time PCR master mix (Toyobo) according to manufacturer's instructions to measure the relative expression of $A B C A 1$ and $A B C G 1$ mRNA. PCR products were amplified $\left(95^{\circ} \mathrm{C}, 1 \mathrm{~min}\right.$; followed by 40 cycles of $95^{\circ} \mathrm{C}, 15 \mathrm{sec}$, and $60^{\circ} \mathrm{C}$, $15 \mathrm{sec}$ ) and analyzed on a CFX96 Touch real-time PCR cycler (Bio-Rad Laboratories, Inc.). Fluorescence threshold cycles (CT) of each sample were compared and normalized with the $\mathrm{CT}$ values of housekeeping gene. The relative expression of $A B C A 1$ and $A B C G 1$ were compared between controls and treatment.

Protein extraction and western blot analysis. Cells were treated with or without simvastatin for $48 \mathrm{~h}$ and then lysed in a lysis buffer $(10 \mathrm{mM}$ Tris, $150 \mathrm{mM} \mathrm{NaCl}, 1 \mathrm{mM}$ EDTA, $0.5 \%$ Triton $\mathrm{X}-100$, and $1 \mathrm{mM}$ PMSF protease inhibitor). Thirty $\mu \mathrm{g}$ proteins were reduced by heating with loading buffer (225 mM Tris, 25\% (v/v) glycerol, $0.75 \mathrm{mM}$ bromophenol blue and $10 \mathrm{mM}$ DTT with $\mathrm{pH} 6.8$ ) at $95^{\circ} \mathrm{C}$ for $10 \mathrm{~min}$ and were separated by discontinuous SDS polyacrylamide gel-electrophoresis (Bio-Rad Laboratories, Inc.). Electrophoresis was performed using a Bio-Rad Mini Trans-Blot Cell at 80 volts for $3 \mathrm{~h}$ and $8 \%$ gels were used for ABCA1, ABCG1, Akt1 and pAkt (ser473). Proteins were transferred to nitrocellulose membranes (HYBOND ECL; GE Healthcare Life Sciences) using Bio-Rad Mini Trans-Blot Cell at 90 volts for $2 \mathrm{~h}$ before being blocked with 5\% skimmed milk in PBS $0.1 \%$ Tween-20 for $1.5 \mathrm{~h}$. Mouse monoclonal anti-actin (AC-15; Abcam), mouse monoclonal anti-ABCA1(AB.H10; EMD Millipore), rabbit monoclonal anti-ABCG1 (EP1366Y; Abcam), mouse monoclonal anti-Akt1 (B-1; Santa Cruz Biotechnology, Inc.) and rabbit monoclonal anti-pAkt (ser473)(D9E, Cell Signaling Technology, Inc.) antibodies were added at $4^{\circ} \mathrm{C}$ for $16 \mathrm{~h}$. Membranes were incubated with HRP-conjugated goat anti-mouse (Invitrogen; Thermo Fisher Scientific, Inc.) and goat anti-rabbit antibody (Invitrogen; Thermo Fisher Scientific, Inc.) diluted in PBS at $25^{\circ} \mathrm{C}$ for $2 \mathrm{~h}$. They were developed by SureBlue TMB membrane substrate (KPL). Band intensity of TMB color was analyzed by ImageJ program (version 1.48).

Cholesterol efflux assay. Cells were seeded at $2 \times 10^{4}$ cells per well in black 96-well plates and incubated for $24 \mathrm{~h}$. Cells were treated with or without cholesterol for $1 \mathrm{~h}$ and replaced with serum-free medium for $24 \mathrm{~h}$ before being treated with or without simvastatin. Cells were then replaced with serum-free medium containing labeling media for $1 \mathrm{~h}$. Labeling medium consisted of bodipy cholesterol (Avanti Polar Lipids), MCD, HEPES (Sigma-Aldrich; Merck KGaA), and egg phosphatidylcholine (Avanti Polar Lipids) and prepared as previously described (28). The final concentrations of bodipy cholesterol, egg phosphatidylcholine, and MCD in the labeling medium were $0.025 \mathrm{mM}, 0.1 \mathrm{mM}$, and $10 \mathrm{mM}$, respectively. Cells were washed with HAM's F12-HEPES and incubated with serum-free medium for $18 \mathrm{~h}$. ApoA-1 and HDL (both from Lee Biosolutions) were added for $6 \mathrm{~h}$ at $100 \mu \mathrm{g} / \mathrm{ml}$ and $70 \mu \mathrm{g} / \mathrm{ml}$, respectively. Cells were dissolved with $1 \%$ cholic acid (Sigma-Aldrich; Merck KGaA) in $1 \mathrm{~N} \mathrm{NaOH}$ for $4 \mathrm{~h}$ with rocking while the supernatant was collected and centrifuged at $10,000 \mathrm{x} \mathrm{g}$ for $5 \mathrm{~min}$. The cholesterol fluorescence intensity value was recorded using a microplate reader (excitation at $482 \mathrm{~nm}$ and emission at $515 \mathrm{~nm}$ ). The \% cholesterol efflux $=$ cholesterol efflux intensity/(intracellular cholesterol + cholesterol efflux) $\times 100 \%$.

Immunofluorescence of $A B C A 1$ and $A B C G 1$ transporter. Cells were seeded at $10^{4}$ cells per well in 96 -well plates and incubated for $24 \mathrm{~h}$. They were treated with or without cholesterol for $1 \mathrm{~h}$ and replaced with serum-free medium for $24 \mathrm{~h}$ before being treated with or without simvastatin. Cells were fixed with 4\% paraformaldehyde in PBS for 20 min and permeabilized with $0.1 \%$ saponin (Sigma-Aldrich; Merck KGaA) in PBS for $15 \mathrm{~min}$. They were then blocked with $2 \%$ FBS in PBS for $1 \mathrm{~h}$ at $25^{\circ} \mathrm{C}$ and incubated with mouse monoclonal anti-ABCA1 (Millipore) and rabbit polyclonal anti-ABCG1 (AAS52436C; Antibody Verify) antibodies at 1:50 dilution at $4^{\circ} \mathrm{C}$ for $16 \mathrm{~h}$. Cells were washed with $0.1 \%$ saponin in PBS and incubated with Alexa flour 488-conjugated goat polyclonal anti-mouse (Invitrogen; Thermo Fisher Scientific, Inc.) and Alexa flour 546-conjugated goat polyclonal anti-rabbit (Invitrogen; Thermo Fisher Scientific, Inc.) antibodies for $2 \mathrm{~h}$. They were counterstained with Hoechst (33342; Molecular Probes) for $10 \mathrm{~min}$. Fluorescence intensity was visualized and photographed using an IX83 inverted fluorescence microscope with CellSens software platform (Olympus Cooperation).

Statistical analysis. Quantitative data are presented as mean \pm SEM. Statistical significance between groups was analyzed using standard t-tests or two-way ANOVA followed by the Bonferroni test. Significant P-values are indicated within the figure panels. Error bars indicate SEM.

\section{Results}

Statin inhibited cell viability and decreased intracellular cholesterol level in KKU-100 cells. The effects of simvastatin, atorvastatin and cholesterol on cell survival and growth of KKU-100 cells were determined by clonogenic assay. These statins caused a concentration-dependent decrease in the colony formation ability of KKU-100 cells. At low concentrations (0.01-10 $\mu \mathrm{M})$, simvastatin and atorvastatin had minimal effects on colony formation of KKU-100 cells. However, they significantly inhibited KKU-100 cell growth at $100 \mu \mathrm{M}$, $(\mathrm{P}<0.001$; Fig. 1A and B). Using the MTT assay, cytotoxic activities of simvastatin and atorvastatin were also observed. Both statins had different levels of cytotoxicity to four CCA cell lines (Fig. S1). Cholesterol increased KKU-100 cell colony formation at $1-10 \mu \mathrm{M}(\mathrm{P}<0.001)$ but decreased it at $100 \mu \mathrm{M}$ $(\mathrm{P}<0.001)$ compared to controls (Fig. 1C).

In order to examine the effect of simvastatin on cell growth and survival in the presence of cholesterol, KKU-100 cells were loaded with $10 \mu \mathrm{M}$ cholesterol prior to being incubated with simvastatin (25-50 $\mu \mathrm{M})$ for $48 \mathrm{~h}$. In the absence of cholesterol, KKU-100 cell viability decreased as the concentration 
$\mathbf{A}$

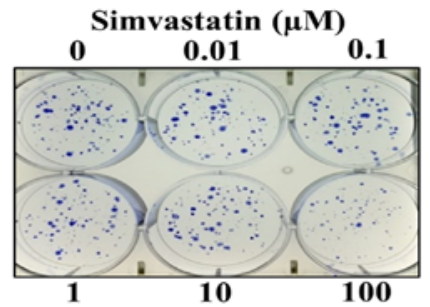

B

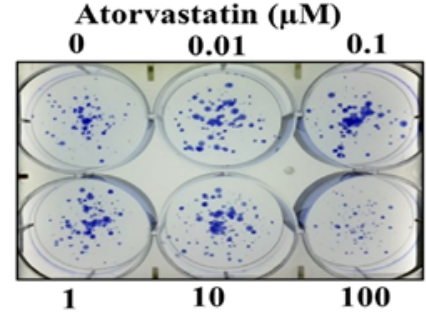

C

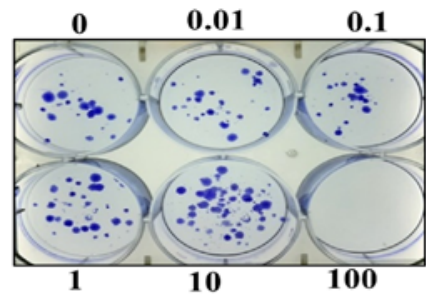

D

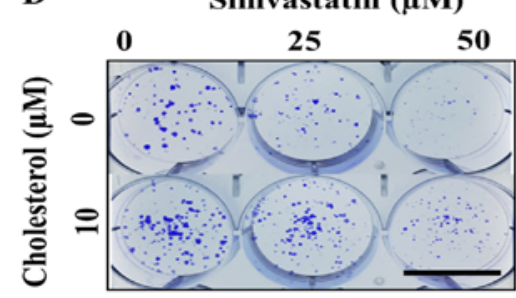

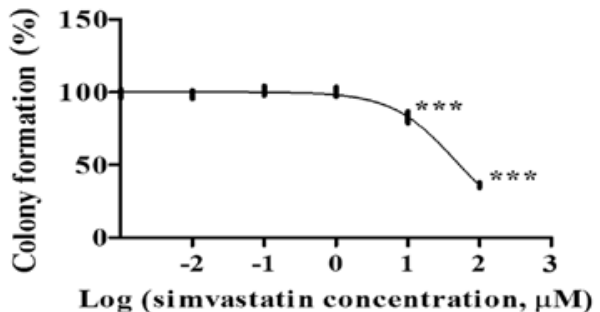

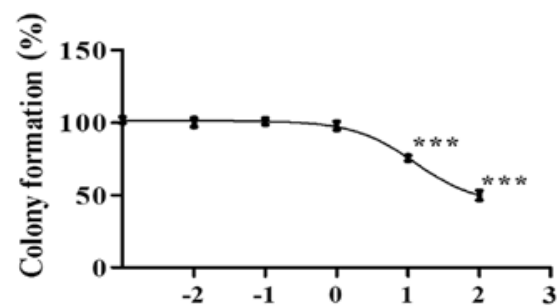

Log (atorvastatin concentration, $\mu M$ )

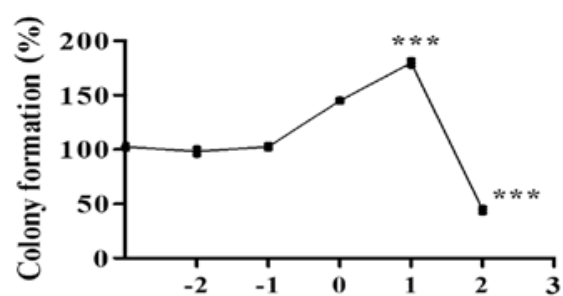

Log (cholesterol concentration, $\mu \mathrm{M})$

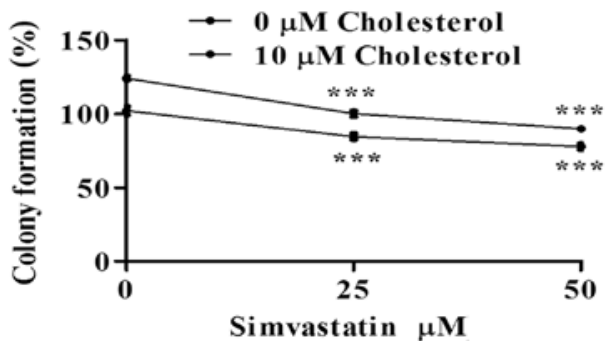

Figure 1. Effect of statins and cholesterol on KKU-100 cell growth. Cells were treated with simvastatin (A) atorvastatin (B) cholesterol (C) and cholesterol and simvastatin (D) for $48 \mathrm{~h}$ at a variety of concentrations. Scale bar=3 cm. After 14 days, cells were stained with crystal violet to examine the colony forming ability. Data shown are representatives of three independent experiments (mean \pm SEM; $n=3$ ). Statistical significance was determined using a Student's t-test. ${ }^{* * * *} \mathrm{P}<0.001$ vs. $0 \mu \mathrm{m}$ treatment.

of simvastatin increased from $25-50 \mu \mathrm{M}$. In the presence of $10 \mu \mathrm{M}$ cholesterol, the reduction of cell viability was observed but at lower degree than that without cholesterol (Fig. 1D).

Oil red o staining revealed that without cholesterol, the level of both intracellular lipids and neutral triglycerides declined as KKU-100 cells were exposed to higher concentrations of simvastatin (Fig. 2A and C). Pre-cholesterol loaded KKU-100 cells showed greater intensity of oil red o suggesting elevated levels of intracellular lipids (Fig. 2D). However, with higher concentration of simvastatin, oil red o staining intensity reduced but at lesser extent than those without cholesterol (Fig. 2D and F). In comparison with $0 \mu \mathrm{M}, \mathrm{KKU}-100$ cell density at 25 and $50 \mu \mathrm{M}$ simvastatin decreased by $44 \%$ $(\mathrm{P}<0.01)$ and by $69 \%(\mathrm{P}<0.05)$, respectively (Fig. 2G). In the presence of $10 \mu \mathrm{M}$ cholesterol, KKU-100 cell density reduced by $26 \%(\mathrm{P}<0.05)$ and by $30 \%(\mathrm{P}<0.05)$, respectively when compared to a control group. (Fig. 2G).

$C C A$ cells expressed $A B C A 1$ and $A B C G 1$ transporters which mediated cholesterol efflux. CCA cell lines were examined for expression of $A B C A 1, A B C G 1, A B C G 5$ and $A B C G 8$ by RT-PCR. RMCCA1 and KKU-100 cells expressed relatively higher levels of $A B C A 1$ and $A B C G 1 \mathrm{mRNA}$ than those of HuCCA-1 and KKU-M213 cells (Fig. 3A and C). Neither $A B C G 5$ nor $A B C G 8$ mRNA was present in CCA cell lines. We were able to detect $A B C G 5$ and $A B C G 8$ only in HepG 2 cells which were used as a liver cancer cell line (Fig. 3B and D).

Western blot analysis revealed that KKU-100 cells expressed the highest level of ABCA1. The expression level of ABCG1 was higher in HuCCA-1, RMCCA-1 and KKU-100 cells but slightly lower in KKU-M213 cells (Fig. 3E). We conducted cholesterol efflux assay using bodipy cholesterol in KKU-100 cells which expressed highest level of ABCA1 and ABCG1. Baseline condition was set in the absence of cholesterol acceptor by which the constitutive efflux was at $6.00 \pm 0.58 \%$ (Fig. 4). By adding Apo-A1, cholesterol translocation which was mediated specifically through ABCA1 increased to $11.33 \pm 1.86 \%$ ( $\mathrm{P}<0.05$; Fig. 4). HDL also triggered cholesterol efflux via ABCG1. Export through this mechanism was obvious at $46.33 \pm 5.33 \%(\mathrm{P}<0.01)$ (Fig. 4). 


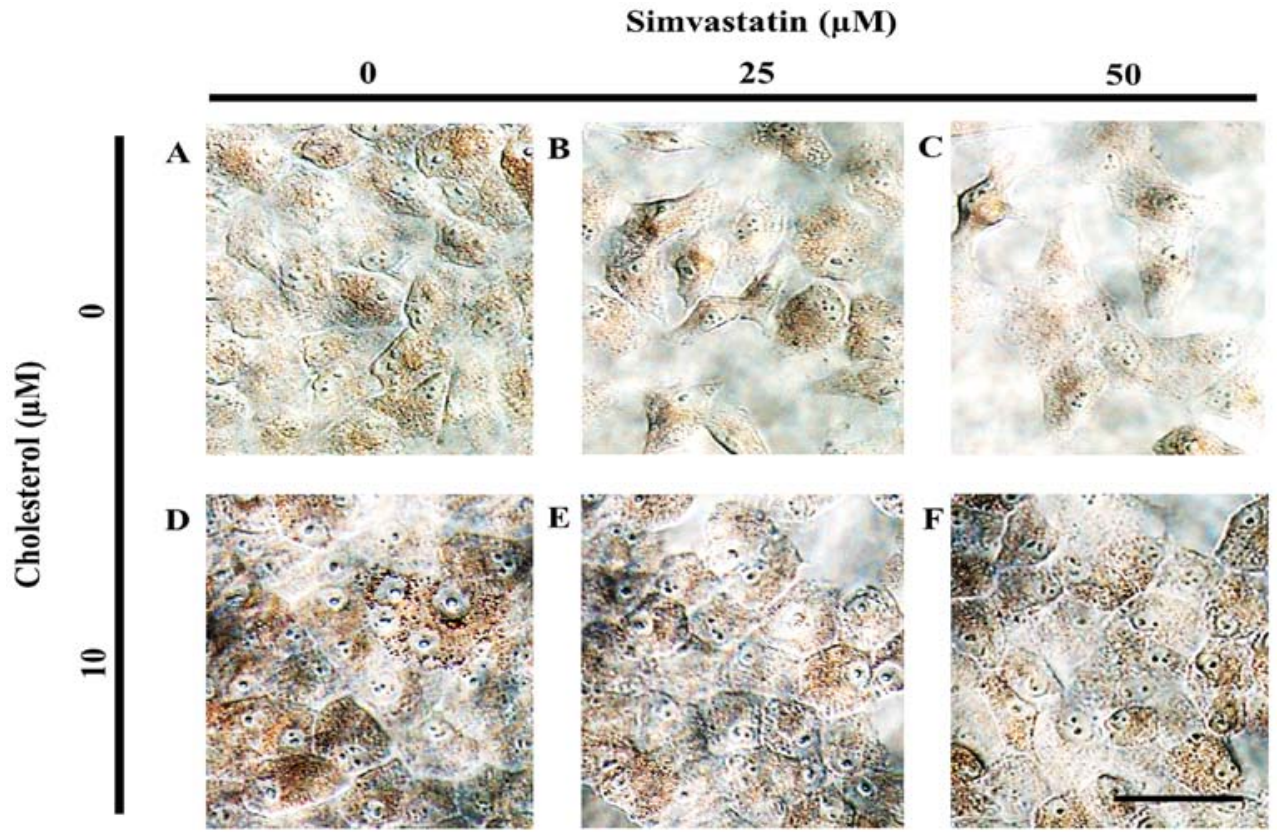

G
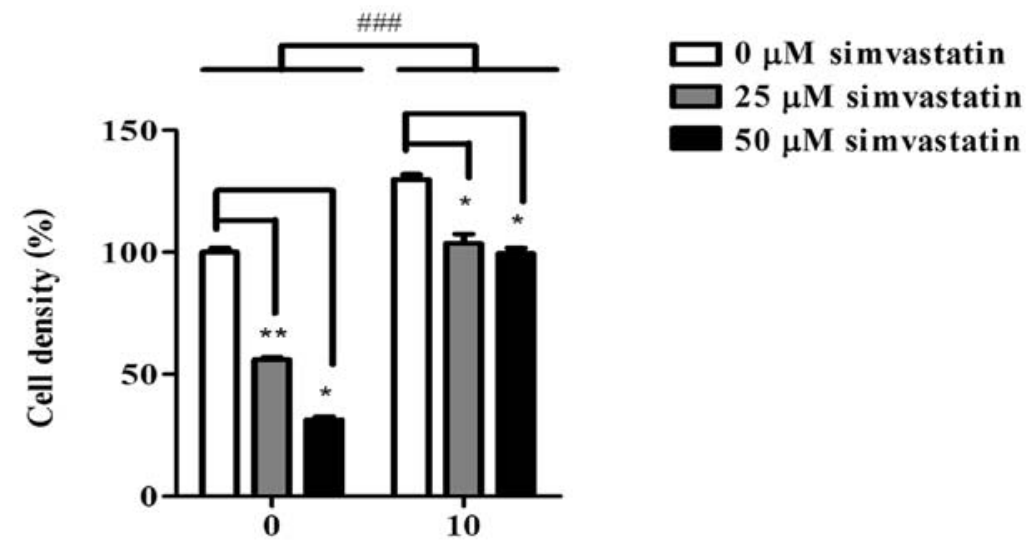

Cholesterol $(\mu \mathrm{M})$

Figure 2. Simvastatin reduced intracellular cholesterol in KKU-100 cells. Light micrographs demonstrated KKU-100 cells that were treated with simvastatin at a variety of concentrations for $48 \mathrm{~h}$. Cells were then fixed and stained with oil red o (dark brown/orange). KKU-100 cells were treated with (A) $0 \mu \mathrm{M}$, (B) $25 \mu \mathrm{M}$ and (C) $50 \mu \mathrm{M}$ of simvastatin. Cells were pre-loaded with $10 \mu \mathrm{M}$ cholesterol before being exposed to (D) $0 \mu \mathrm{M}$, (E) $25 \mu \mathrm{M}$ and (F) $50 \mu \mathrm{M}$ of simvastatin (G) Semi-quantitative of cell density was analyzed in each condition (mean \pm SEM; $n=3$ ). Statistical significance was determined using a two-way ANOVA test with Kendall's tau correlation. ${ }^{*} \mathrm{P}<0.05 ;{ }^{* *} \mathrm{P}<0.01$ comparison between 25,50 and $0 \mu \mathrm{M}$ groups; ${ }^{\# \# /} \mathrm{P}<0.001$ vs. comparison between pre-cholesterol loaded and no cholesterol loaded cells. Scale bar=50 $\mu \mathrm{m}$ for A-F.

Simvastatin decreased ABCA1 and ABCGl expression. The effect of simvastatin on ABCA1 and ABCG1 expression was evaluated by real-time PCR and western blot analysis. Compared to control, at 25 and $50 \mu \mathrm{M}$ of simvastatin treatment, the relative levels of $A B C A 1$ mRNA expression decreased significantly by $72 \%(\mathrm{P}<0.001)$ and by $91 \%(\mathrm{P}<0.001)$, respectively (Fig. 5A). Compared to control, at 25 and $50 \mu \mathrm{M}$ of simvastatin treatment, the relative levels of $A B C G 1$ mRNA expression decreased significantly by $78 \%(\mathrm{P}<0.001)$ and by 93\% $(\mathrm{P}<0.001)$, respectively (Fig. $5 \mathrm{~B})$. Following exposure of cholesterol at $10 \mu \mathrm{M}, \mathrm{KKU}-100$ cells showed significantly enhanced ABCA1 and ABCG1 expression at 50\% ( $\mathrm{P}<0.001)$ and $60 \%(\mathrm{P}<0.001)$, respectively comparing to no cholesterol loaded cells (Fig. 5A and B). However, with 25 and $50 \mu \mathrm{M}$ simvastatin, expression of ABCA1 and ABCG1 decreased in a concentration-dependent manner (Fig. 5A and B).
Simvastatin also caused a concentration-dependent decrease in the levels of ABCA1 and ABCG1 protein expression in KKU-100 cells. (Fig. 6A). At $25 \mu \mathrm{M}$ of simvastatin treatment, relative $\mathrm{ABCA} 1$ and $\mathrm{ABCG} 1$ proteins were reduced by $15 \%(\mathrm{P}<0.05)$ and by $8 \%$, respectively (Fig. $6 \mathrm{D}$ and $\mathrm{E})$. Expression of ABCA1 and ABCG1 protein at $50 \mu \mathrm{M}$ of simvastatin treatment were drastically decreased by $79 \%(\mathrm{P}<0.001)$ and by $61 \%(\mathrm{P}<0.01)$, respectively (Fig. $6 \mathrm{D}$ and E). Following exposure of cholesterol at $10 \mu \mathrm{M}, \mathrm{KKU}-100$ cells showed enhanced $\mathrm{ABCA} 1$ and $\mathrm{ABCG1}$ expression at $177 \%(\mathrm{P}<0.001)$ and $100 \%(\mathrm{P}<0.001)$, respectively comparing to no cholesterol loaded cells (Fig. 6D and E). However, with 25 and $50 \mu \mathrm{M}$ simvastatin, expression of $\mathrm{ABCA} 1$ and $\mathrm{ABCG} 1$ decreased in a concentration-dependent manner (Fig. 6A).

In order to investigate the role of Akt in $\mathrm{ABCA} 1$ and ABCG1 expression in KKU-100 cells, Akt and pAkt (ser473 
A
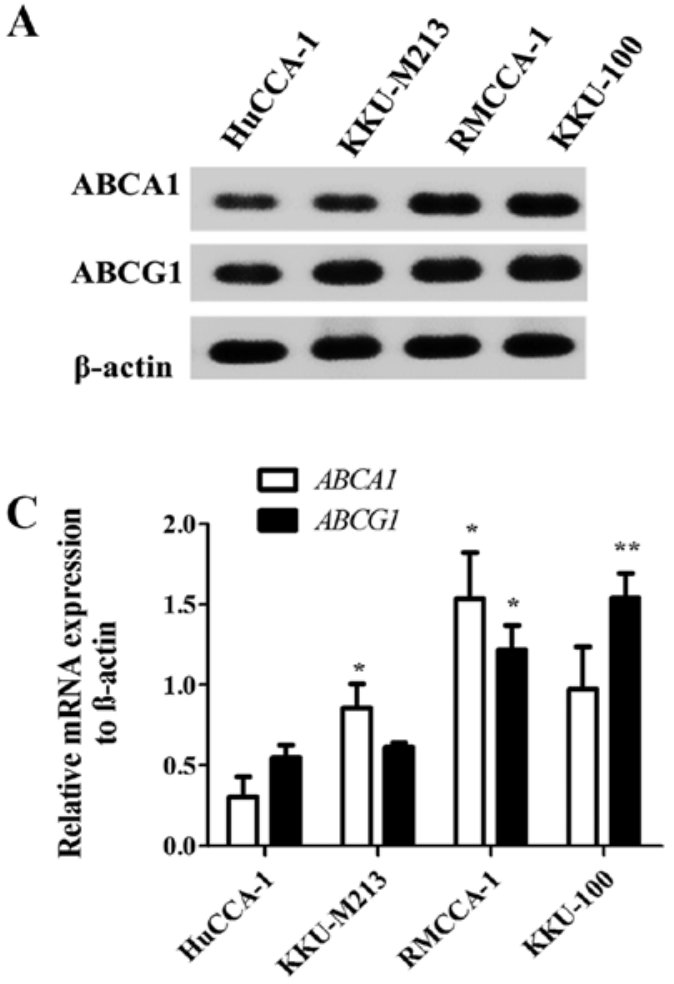

B

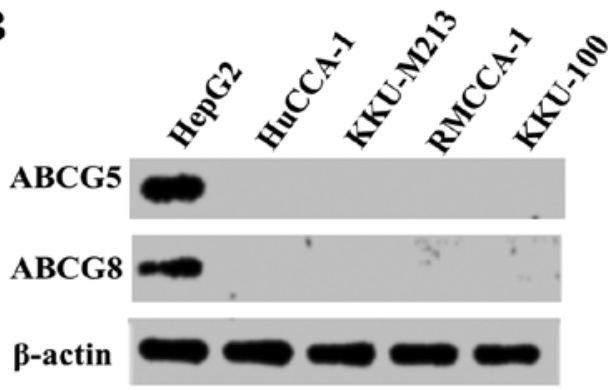

D

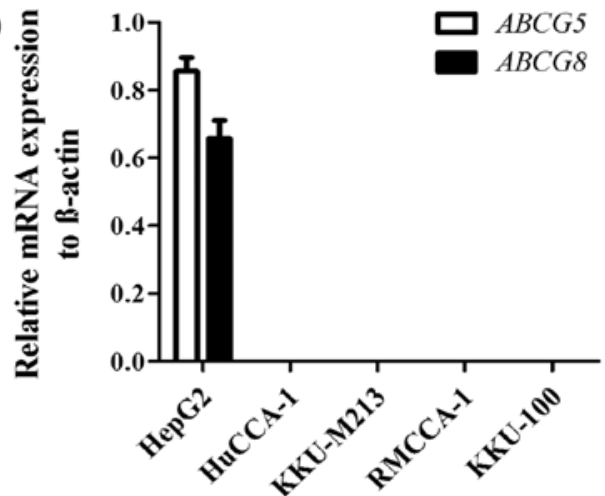

$\mathbf{E}$

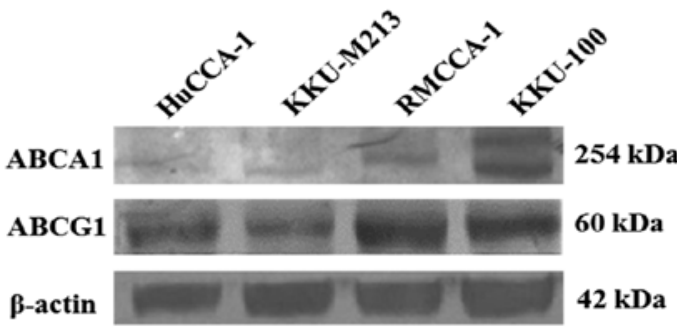

Figure 3. mRNA and protein expression of ABCA1 and ABCG1, but ABCG5 and ABCG8 are not identified in the four CCA cell lines. A total of four CCA cell lines were evaluated for (A) ABCA1 and ABCG1 mRNA expression and (B) ABCG5 and ABCG8 (B) using RT-PCR. Semi-quantitative analysis was used to measure (C) ABCA1 and ABCG1 mRNA expression (C) and (D) ABCG5 and ABCG8 mRNA expression (mean \pm SEM; $n=3$ ). For ABCG5 and ABCG8 mRNA expression, the HepG2 cell line was used as a positive control. Protein expression of ABCA1 and ABCG1 was performed using (E) western blot analysis. Statistical significance was determined using a Student's t-test. ${ }^{*} \mathrm{P}<0.05 ;{ }^{* *} \mathrm{P}<0.01$ vs. HuCCA-1 cells. RT, reverse transcription; CCA, cholangiocarcinoma; ABC, ATP-binding cassette.

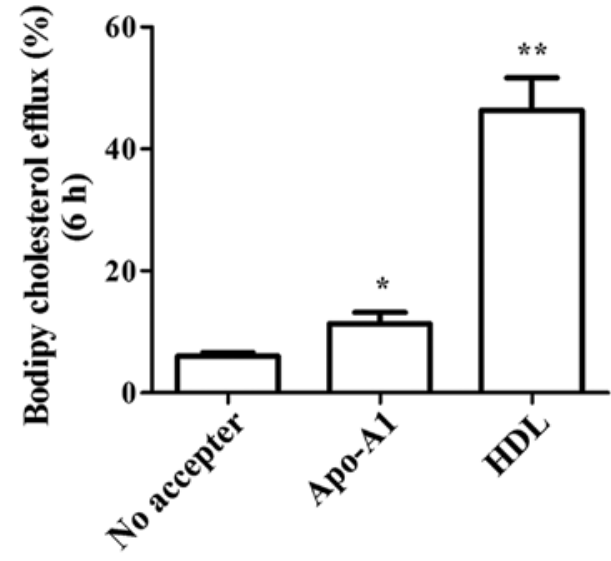

Figure 4. Cholesterol transport via ABCA1 and ABCG1 in KKU-100 cells. After loading cholesterol, ABCA1 and ABCG1 mediated efflux in KKU-100 cells were analyzed using specific cholesterol acceptors, $100 \mu \mathrm{g} / \mathrm{ml}$ Apo-A1 and $70 \mu \mathrm{g} / \mathrm{ml} \mathrm{HDL}$, respectively (mean $\pm \mathrm{SEM} ; \mathrm{n}=3$ ). Statistical significance was determined using a Student's t-test. " $\mathrm{P}<0.05 ;{ }^{* *} \mathrm{P}<0.01$ vs. no acceptor. $\mathrm{ABC}, \mathrm{ATP}$-binding cassette; HDL, high density lipoprotein. protein expression were evaluated (Fig. 6A). KKU-100 cells constitutively expressed Akt and pAkt (ser473) (Fig. 6B and C). Nonetheless, in the presence of simvastatin, KKU-100 cells retained the levels of those proteins (Fig. 6B and C). Exposures of cholesterol at $10 \mu \mathrm{M}$ did not noticeably alter the level of Akt and pAkt (ser473) expression (Fig. 6B and C). Among pre-cholesterol loaded KKU-100 cells, levels of those proteins were comparable between simvastatin-treated and non-treated cells suggesting the Akt-independent manner of ABCA1 and ABCG1 expression in KKU-100 cells (Fig. 6B).

Intracellular localization of $A B C A 1$ and $A B C G 1$ in $K K U-100$ cells. We visualized the intracellular expression of ABCA1 and ABCG1 in KKU-100 cells by immunocytochemistry. The expression of ABCA1 (green) was observed within cytoplasm. Intense staining of $A B C A 1$ was detected particularly in the proximity of the nucleus (Fig. 7A). Similar to ABCA1, ABCG1 expression was recorded in the cytoplasmic region of KKU-100 cells. However, the staining showed a more dispersed pattern 
A

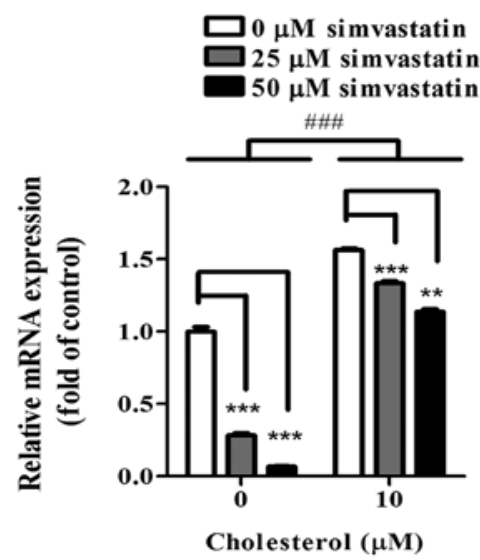

B

ABCG1

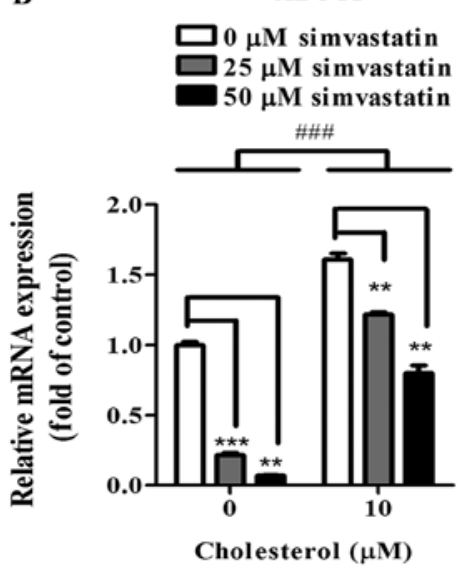

Figure 5. Simvastatin reduced mRNA expression of ABCA1 and ABCG1 in KKU-100 cells. Cells were treated with simvastatin at a variety of concentrations for $48 \mathrm{~h}$. Determination of (A) ABCA1 and (B) ABCG1 mRNA expression was performed using qPCR analysis (mean \pm SEM). Statistical significance was determined using a two-way ANOVA analysis with Kendall's tau correlation. ${ }^{* *} \mathrm{P}<0.01 ;{ }^{* * *} \mathrm{P}<0.001$ comparison between 25,50 and $0 \mu \mathrm{M}$ simvastatin and

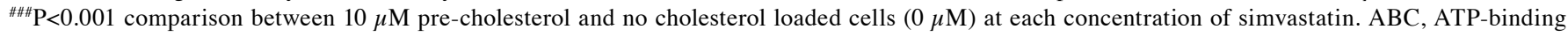
cassette; q, quantitative.

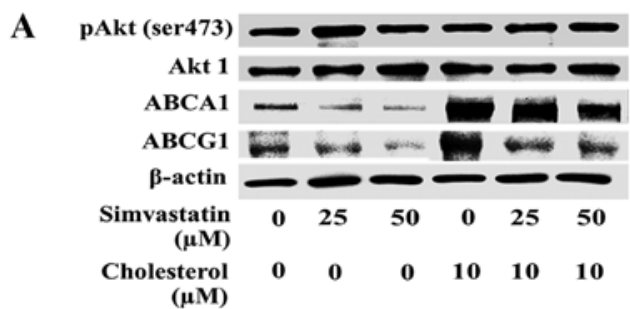

B

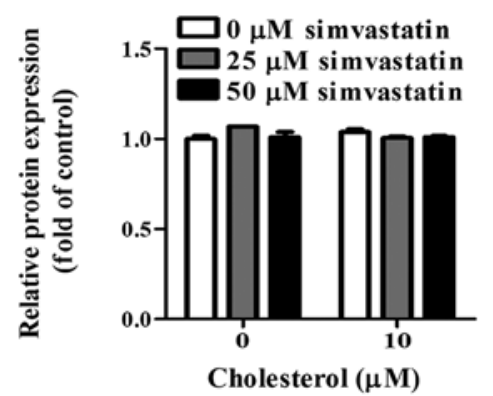

D

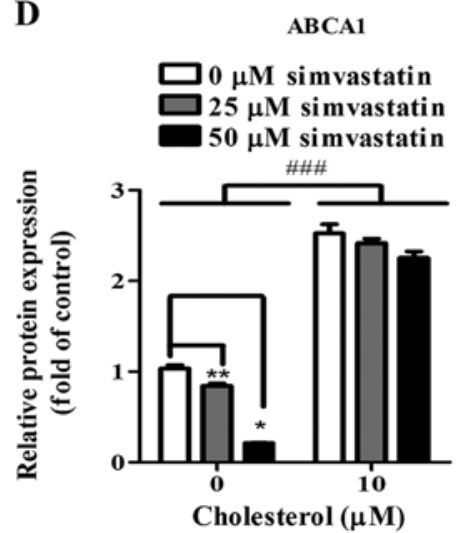

C

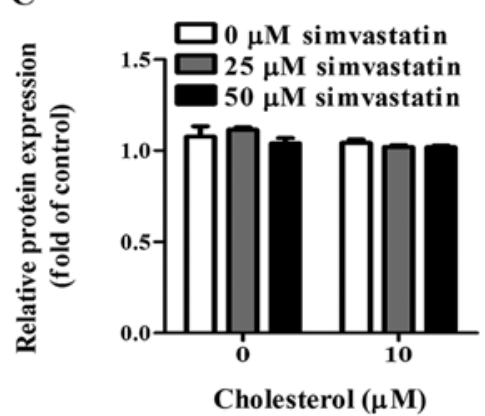

E

ABCG 1

$\square 0 \mu \mathrm{M}$ simvastatin $\square 25 \mu \mathrm{M}$ simvastatin $50 \mu \mathrm{M}$ simvastatin \#\#\#

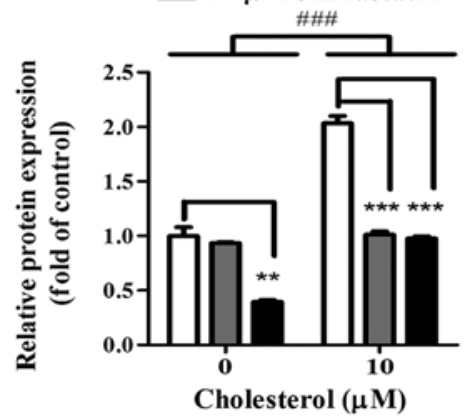

Figure 6. Simvastatin reduced ABCA1 and ABCG1, but not Akt1 and pAkt (ser473) in KKU-100 cells. Cells were treated with simvastatin at a variety of concentrations for $48 \mathrm{~h}$. Cells were then evaluated for protein expression of Akt, pAkt (ser473), ABCA1 and ABCG1 were determined using (A) western blot analysis. Band intensity was analyzed and relative expression of (B) pAkt (ser473), (C) Akt, (D) ABCA1 and (E) ABCG1 were calculated (mean \pm SEM; n=3). Statistical significance was determined using a two-way ANOVA with Kendall's tau correlation. ${ }^{*} \mathrm{P}<0.05 ;{ }^{* *} \mathrm{P}<0.01 ;{ }^{* * *} \mathrm{P}<0.001$ compared between 25,50 and $0 \mu \mathrm{M}$ simvastatin; ${ }^{\# \# \#} \mathrm{P}<0.001$ compared between $10 \mu \mathrm{M}$ pre-cholesterol and no cholesterol loaded cells $(0 \mu \mathrm{M})$ at each concentration of simvastatin. $\mathrm{ABC}$, ATP-binding cassette. 


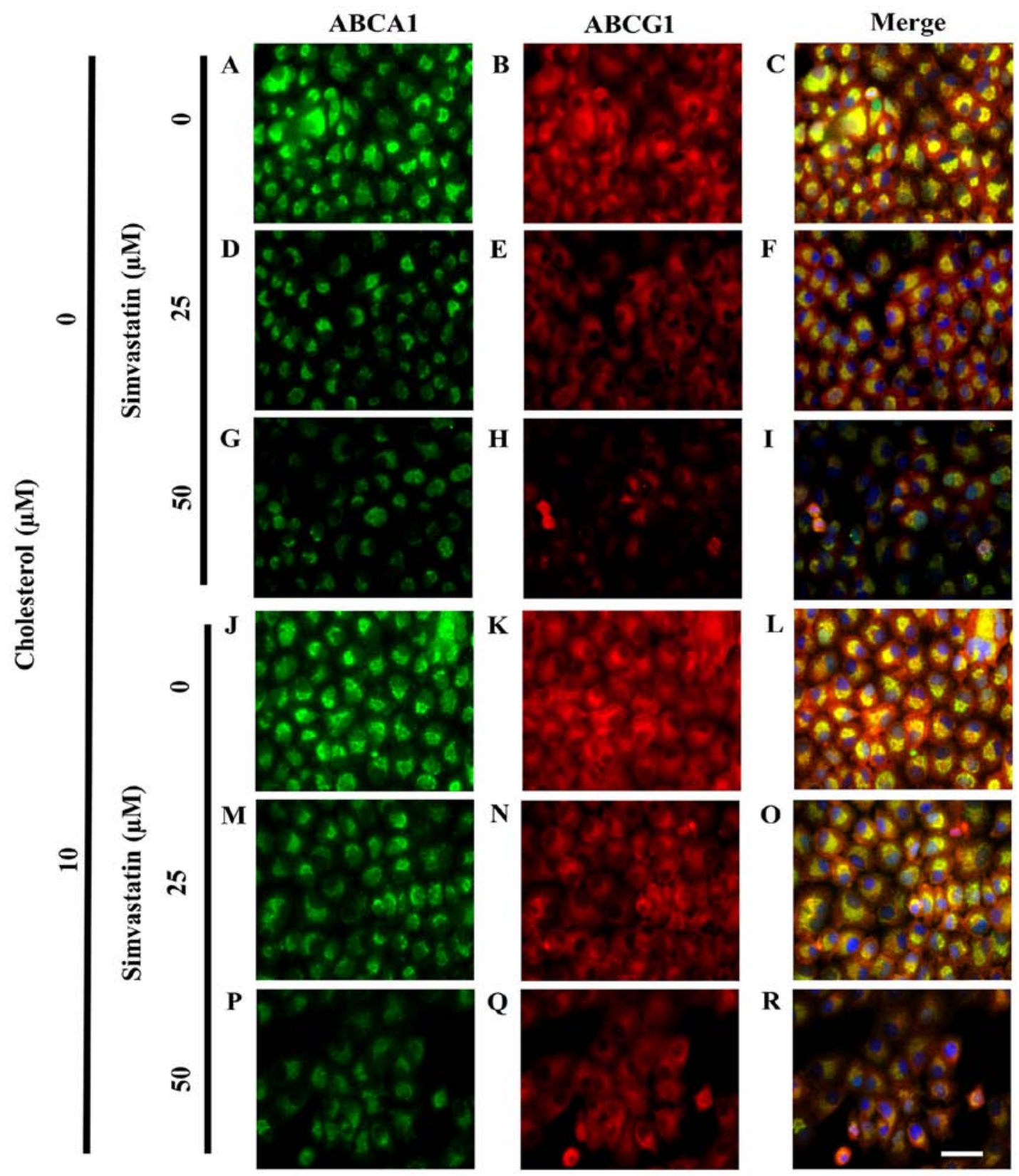

Figure 7. Cholesterol loading prevented simvastatin-induced reduction of ABCA1 and ABCG1 expression in KKU-100 cells. Fluorescence micrographs show cells which were loaded with cholesterol before being treated with simvastatin at various concentrations for $48 \mathrm{~h}$. They were fixed, permeabilized and stained using specific antibodies against ABCA1 (green) and ABCG1 (red). Hoechst (blue) was counterstained for nucleus. At $0 \mu \mathrm{M}$ simvastatin, the localization of (A) ABCA1, (B) ABCG1 and the (C) co-localization of ABCA1 and ABCG1 were determined. KKU-100 cells were treated with $25 \mu \mathrm{M}$, the localization of (D) ABCA1, (E) ABCG1 and the (F) co-localization of ABCA1 and ABCG1 were examined. With $50 \mu \mathrm{M}$ of simvastatin, the expression of (G) ABCA1, (H) ABCG1 and (I) ABCA1 and ABCG1 were localized in KKU-100 cells. In pre-cholesterol loading condition, $(10 \mu \mathrm{M})(\mathrm{J}-\mathrm{R})$, at $0 \mu \mathrm{M}$ simvastatin, the localization of (J) ABCA1, (K) ABCG1 and the (L) co-localization of ABCA1 and ABCG1 were determined. At $25 \mu \mathrm{M}$ simvastatin, the localization of (M) ABCA1, (N) ABCG1 and the $(\mathrm{O})$ co-localization of $\mathrm{ABCA} 1$ and $\mathrm{ABCG} 1$ were examined with $50 \mu \mathrm{M}$ of simvastatin, the expression of (P) $\mathrm{ABCA} 1,(\mathrm{Q}) \mathrm{ABCG} 1$ and (R) ABCA1 and ABCG1 were localized in KKU-100 cells. Scale bar is $50 \mu \mathrm{m}$ for A-R. Scale bar=50 $\mu \mathrm{m}$ for A-R. ABC, ATP-binding cassette.

of ABCG1 expression (red). This transporter could be detected throughout the cytoplasm and in the submembrane region (Fig. 7B and C). Co-localization of ABCA1 and ABCG1 staining showed overlapping expression of these two transporters (Fig. 7C). Following simvastatin treatment, at $25 \mu \mathrm{M}$, KKU-100 cells exhibited lower levels of both ABCA1 and ABCG1 expression (Fig. 7D and F). Simvastatin seemed to act in a concentration-dependent manner as lower expression of these two transporters was observed at higher concentration $(50 \mu \mathrm{M})$ of simvastatin (Fig. $7 \mathrm{G}$ and I).
Pre-exposure to cholesterol minimized simvastatin effect in CCA cells. Following exposure to cholesterol at $10 \mu \mathrm{M}$, KKU-100 cells showed enhanced ABCA1 and ABCG1 expression (Fig. 7J and L). With $25 \mu \mathrm{M}$ simvastatin, KKU-100 cells retained expression of ABCA1 and ABCG1 in pre-cholesterol loaded cells compared with non-loaded cells (Fig. 7M and O). This expression was greatly decreased at greater simvastatin condition $(50 \mu \mathrm{M})$. However with cholesterol, expressions of both $\mathrm{ABCA} 1$ and $\mathrm{ABCG} 1$ was more visible (Fig. 7P and R) than those without the pre-exposure to cholesterol (Fig. 7G and I). 

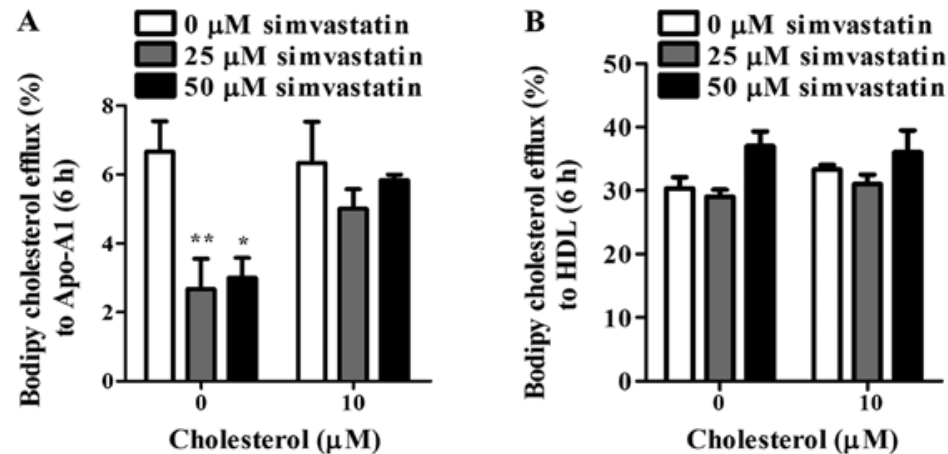

Figure 8. Effect of cholesterol and simvastatin on ABCA1 and ABCG1 mediated export. After loading cholesterol, lipid efflux in CCA cell lines was analyzed using specific cholesterol acceptors, (A) $100 \mu \mathrm{g} / \mathrm{ml}$ Apo-A1 and (B) $70 \mu \mathrm{g} / \mathrm{ml}$ HDL (mean \pm SEM; $\mathrm{n}=3$ ). Statistical significance was determined using a two-way ANOVA with Kendall's tau correlation. ${ }^{*} \mathrm{P}<0.05 ;{ }^{* *} \mathrm{P}<0.01$ compared between 25,50 and $0 \mu \mathrm{M}$ simvastatin. ABC, ATP-binding cassette; CCA, cholangiocarcinoma.

Different effect of simvastatin on cholesterol transport in CCA cells. The effect of simvastatin on cholesterol efflux was further examined. Cholesterol export through ABCA1 in simvastatin-treated KKU-100 cells decreased by $60 \%(\mathrm{P}<0.01)$ and $55 \%(\mathrm{P}<0.05)$ at 25 and $50 \mu \mathrm{M}$ simvastatin, respectively comparing to non-treated controls (Fig. 8A). Interestingly, pre-exposure of KKU-100 cells to cholesterol did not change the ABCA1-mediated function, although these cells showed up-regulated ABCA1 expression levels. In simvastatin treatment, efflux to Apo-A1 of pre-cholesterol loaded KKU-100 cells decreased but only at marginal levels (Fig. 8A). For ABCG1 function, simvastatin-treated cells showed similar levels of cholesterol export to HDL to non-treated cells (Fig. 8B). Under stimulation of cholesterol, simvastatin had no considerable effect on this cholesterol efflux compared to controls. ABCG1 knockdown experiment was performed in HuCCA-1 cells using RNA interference. siABCG1 transfection successfully decreased ABCG1 expression level (Fig. S2). However, comparable cholesterol efflux to HDL was found between siABCG1 cells and non-silenced (wild-type) cells (Fig. S3).

\section{Discussion}

In our study, cholesterol is found to play an important role in CCA cell viability. We demonstrated that cholesterol (1-10 $\mu \mathrm{M})$ significantly increased KKU-100 cell viability. Growth promoting effect of cholesterol was also reported in another CCA study (18). Similar to our findings, cholesterol increased prostate cancer cell proliferation (21). In addition, in vivo experiments revealed that high fat diet-fed mice showed enhanced breast tumor size and metastasis compared with normal diet fed mice (29). By increasing intracellular cholesterol viability, this favored cancer cell proliferation because cholesterol is an important component for cell membrane synthesis (30). However, at a very high cholesterol concentration $(100 \mu \mathrm{M})$, a significant decrease in CCA cell proliferation was found. Studies in gastric carcinoma and neuroblastoma cells also revealed this phenomenon. High cholesterol concentrations caused cytotoxicity which then decreased cell proliferation and induced cell apoptosis $(31,32)$. High accumulation of cholesterol also caused foam cell formation in macrophages leading to their malfunction in preventing the atherosclerosis (33). Exposure to high cholesterol enhanced macrophage cell apoptosis via the mitochondrial Fas signaling pathway (33). These studies emphasize cholesterol as a cell growth driving substance and its homeostasis is also important in cell survival, growth, proliferation and apoptosis.

Statins have been well studied in term of their cholesterol lowering ability. They have been widely used to treat hyperlipidemia in humans. Natural cholesterol sources are from plasma cholesterol which is obtained from cholesterol biosynthesis and from intestinal absorption. Statins reduced serum lipids by suppressing cholesterol biosynthesis which eventually caused decrease in cell viability $(18,19,34,35)$. In our experiments, simvastatin reduced intracellular cholesterol level of KKU-100 cells which is similar to other CCA studies that simvastatin suppressed endogenous cholesterol synthesis (18) through the reduced HMG-CoA reductase activity (36). Nonetheless, these effects of simvastatin were prevented in the presence of cholesterol. Cholesterol-loading CCA cells negated the decreased intracellular cholesterol and decreased cell viability under simvastatin $(25 \mu \mathrm{M})$ exposure. Recent findings elsewhere also showed that pre-cholesterol exposure of various cancer cells including CCA, esophageal adenocarcinoma, macrophages, and T-cell leukemia elevated unesterified cholesterol pools $(18,37-41)$. It is therefore possible that unesterified cholesterol supply resist the effect of simvastatin $(18,39,41,42)$.

In our paper, we confirm that in $\mathrm{CCA}, \mathrm{ABCA} 1$ and ABCG1 transporters mediate cholesterol efflux to Apo-A1 and HDL, respectively. These transporters are well-known as predominant cholesterol transporters in macrophages and hepatocarcinoma assisting cholesterol export and maintaining cholesterol homeostasis (11-14). ABCA1 is localized in proximity to the nucleus and spread throughout the cytoplasm of KKU-100 cells. In fibroblasts, ABCA1-mediated cellular cholesterol transport also occurs in late endosome (43). Apo-A1 is trafficked via ABCA1 from cell membrane into late endosome in which lipidated Apo-A1 would subsequently become nascent HDL (43). ABCG1 is dominantly found perinuclear endosomes and plasma membrane. In ABCG1-transfected HeLa cells, ABCG1 mediates cholesterol efflux by either vesicular or non-vesicular pathway (44). ABCG1-mediated intracellular cholesterol would be shuttled from late endocytic compartment to the cell membrane in order to deliver 
cholesterol to extracellular HDL In this study, we could not detect either ABCG5 or ABCG8 expression in our four CCA cell lines used. These transporters are well studied, showing high expression in hepatocarcinoma cells assisting cholesterol export as a part of bile composition (45). Therefore, we speculated that for CCA cells, ABCA1 and ABCG1, but not ABCG5 and ABCG8 potentially play role in cholesterol transport. We demonstrated here in our work that CCA cells constitutively exported cholesterol via ABCG1 to HDL to a greater extent than to Apo-A1 which was mediated through ABCA1. This was similar to cholesterol export levels in macrophages $(28,46)$. This suggests a smaller range of cholesterol translocation ability of ABCA1 compared to ABCG1.

Further examination was carried out to identify the effects of simvastatin on ABCA1 and ABCG1 levels in CCA cell lines. Our experiments are consistent with previous results that ABCA1 and ABCG1 level decreased in simvastatin treatment. The influence of simvastatin on cholesterol homeostasis genes has been shown in a variety of cancer cell lines $(37,47)$. Statin treatment caused reduction in ABCA1 and ABCG1 expression in epithelial colorectal adenocarcinoma cells (47) and macrophages (37). This supported the theory that simvastatin decreased intracellular cholesterol synthesis, thereby limiting mevalonate and sources of oxysterol production. Oxysterols are important for the nuclear receptor, LXR, in maintaining cholesterol homeostasis (48). In macrophages, LXR controls ABCA1 and ABCG1 activation (49). Therefore, the condition which low mevalonate together with oxysterols triggers down-regulation of ABCA1 and ABCG1 expression caused by statins could occur in CCA. Further experiments on the quantification of mevalonate and oxysterols would clarify this point. In this paper, cholesterol efflux to Apo-A1 decreased under simvastatin treatment suggesting a possible role of ABCA1 in KKU-100 cells. Cholesterol efflux to Apo-A1 was reduced in simvastatin treated macrophages $(37,39)$. Our results suggest that the inhibitory effect of simvastatin could be specific to efflux to Apo-A1 but not to HDL, and more apparent in non-cholesterol loaded cells. Cholesterol-loaded cells reversed the effect of simvastatin in cholesterol translocation to Apo-A1. Relevant pathways and ligands such as those in LXR signaling were possibly restored under cholesterol-loaded conditions reversing the effects of simvastatin at certain concentrations $(37,39)$. In contrast, other papers revealed a simvastatin-facilitated increment in ABCA1 levels and function in hepatocarcinoma cells which displayed an atheroprotective effect of simvastatin via peroxisome proliferator-activated receptors (PPARs) (37).

The role of Akt has been reported with cholesterol availability and growth of certain cancer cells $(18,22,37)$. Downregulation of Akt signaling together with decreased proliferation was detected in glioblastoma after statin treatment (22). Inhibition of pAkt by treating with the MK2206 molecule reduced CCA cell growth (50). We speculated that a decrease in CCA cell proliferation under simvastatin would involve the Akt pathway. The levels of Akt and pAkt (serine473) of KKU-100 cells were analyzed. Neither total Akt nor pAkt expression level was affected in these cells under simvastatin treatment. It had similarly shown in pancreatic cancer cells that atorvastatin did not inhibit total Akt levels (51). Also, in the long-term treatment of the non-small lung cancer A549 cell line with atorvastatin, the level of pAkt (serine473) did not alter. As previously indicated by Miraglia and colleagues that a purinergic receptor $\mathrm{P} 2 \mathrm{X} 7$ was a specific target of statin and indeed only nuclear level of Akt was downregulated by statin (52), additional analysis of nuclear and cytoplasmic levels of those proteins in KKU-100 cells would clarify the actual Akt expression. The ABCA1 regulation has been reported with an Akt-dependent pathway in macrophages and hepatocytes $(23,24)$. Nonetheless, our results presented otherwise that down-regulation of ABCA1 and ABCG1 was not through the Akt pathway. Disruption in lipid rafts and ABCA1 and ABCG1 transporters could be associated with LXR pathways (49). Further investigation to demonstrate the link between the LXR and ABCA1 and ABCG1 pathways has currently been carried out.

To summarize, we demonstrated that ABCA1 and ABCG1 potentially play roles in cholesterol translocation in CCA cells. Simvastatin decreased CCA cell viability, intracellular cholesterol and ABCA1 and ABCG1 expression by an Akt-independent pathway. However, pre-exposure of KKU-100 cells to cholesterol reduced the effect of statins on cell viability and intracellular cholesterol levels. Cholesterol export via ABCA1 and ABCG1 remained unaffected in cholesterol-loaded KKU-100 cells in the presence of simvastatin. This indicates the limitations of statin treatment in CCA patients suffering with hypercholesterolemia.

\section{Acknowledgements}

The authors would like to thank Professor Philip D. Round, Department of Biology, Mahidol University for critical manuscript reading.

\section{Funding}

The current study was supported by National Research Council of Thailand (NRCT; grant no. 2559-A1.8). PS was awarded the 2016 NRCT postgraduate scholarship and research assistantship from Mahidol University. TJ and RT were recipients of the Thailand Research fund and the Medical Research Council (UK), Newton Fund Project (grant nos. DBG 5980006 and MR/N01247X/1).

\section{Availability of data and materials}

The datasets used and/or analyzed during the present study are available from the corresponding author on reasonable request.

\section{Authors' contributions}

PS, TJ, TK and SK designed the study. PS, SK and RT performed the experiments. PS, TJ, TK, and SK analyzed the data. PS and SK wrote the manuscript. All authors reviewed the manuscript and approved the final version.

\section{Ethics approval and consent to participate}

All experimental procedures were performed in compliance with institutional requirements and were approved by the Institutional Ethics Committee of Mahidol University. 


\section{Patient consent for publication}

Not applicable.

\section{Competing interests}

The authors declare that they have no competing interests.

\section{References}

1. Espey DK, Wu XC, Swan J, Wiggins C, Jim MA, Ward E, Wingo PA, Howe HL, Ries LA, Miller BA, et al: Annual report to the nation on the status of cancer, 1975-2004, featuring cancer in American Indians and Alaska Natives. Cancer 110: 2119-2152, 2007.

2. Parkin DM, Srivatanakul P, Khlat M, Chenvidhya D, Chotiwan P, Insiripong S, L'Abbé KA and Wild CP: Liver cancer in Thailand. I. A case-control study of cholangiocarcinoma. Int J Cancer 48: 323-328, 1991.

3. Dhanasekaran R, Hemming AW, Zendejas I, George T, Nelson DR, Soldevila-Pico C, Firpi RJ, Morelli G, Clark V and Cabrera R: Treatment outcomes and prognostic factors of intrahepatic cholangiocarcinoma. Oncol Rep 29: 1259-1267, 2013.

4. Lieser MJ, Barry MK, Rowland C, Ilstrup DM and Nagorney DM: Surgical management of intrahepatic cholangiocarcinoma: A 31 year experience. J Hepatobiliary Pancreat Surg 5: 41-47, 1998.

5. Ma KL, Ruan XZ, Powis SH, Chen Y, Moorhead JF and Varghese Z: Inflammatory stress exacerbates lipid accumulation in hepatic cells and fatty livers of apolipoprotein E knockout mice. Hepatology 48: 770-781, 2008.

6. Rao RK and Samak G: Bile duct epithelial tight junctions and barrier function. Tissue Barriers 1: e25718, 2013.

7. Hofmann AF: The enterohepatic circulation of bile acids in mammals: Form and functions. Front Biosci (Landmark Ed) 14: 2584-2598, 2009.

8. Tabibian JH, Masyuk AI, Masyuk TV, O'Hara SP and LaRusso NF: Physiology of cholangiocytes. Compr Physiol 3: 541-565, 2013.

9. Nachtergaele S, Mydock LK, Krishnan K, Rammohan J, Schlesinger PH, Covey DF and Rohatgi R: Oxysterols are allosteric activators of the oncoprotein smoothened. Nat Chem Biol 8: 211-220, 2012

10. Olkkonen VM, Béaslas O and Nissilä E: Oxysterols and their cellular effectors. Biomolecules 2: 76-103, 2012

11. Zeng Y, Peng Y, Tang K, Wang YQ, Zhao ZY, Wei XY and Xu XL: Dihydromyricetin ameliorates foam cell formation via LXR $\alpha$-ABCA1/ABCG1-dependent cholesterol efflux in macrophages. Biomed Pharmacother 101: 543-552, 2018.

12. Li Y, Jiang B, Liang P, Tong Z, Liu M, Lv Q, Liu Y, Liu X, Tang Y and Xiao X: Nucleolin protects macrophages from oxLDL-induced foam cell formation through up-regulating ABCA1 expression. Biochem Biophys Res Commun 486: 364-371, 2017.

13. Wang X, Collins HL, Ranalletta M, Fuki IV, Billheimer JT, Rothblat GH, Tall AR and Rader DJ: Macrophage ABCA1 and ABCG1, but not SR-BI, promote macrophage reverse cholesterol transport in vivo. J Clin Invest 117: 2216-2224, 2007.

14. Basso F, Freeman L, Knapper CL, Remaley A, Stonik J, Neufeld EB, Tansey T, Amar MJ, Fruchart-Najib J, Duverger $\mathrm{N}$, et al: Role of the hepatic ABCA1 transporter in modulating intrahepatic cholesterol and plasma HDL cholesterol concentrations. J Lipid Res 44: 296-302, 2003.

15. Feng B and Tabas I: ABCA1-mediated cholesterol efflux is defective in free cholesterol-loaded macrophages. Mechanism involves enhanced $\mathrm{ABCA} 1$ degradation in a process requiring full NPC1 activity. J Biol Chem 277: 43271-43280, 2002.

16. Lee BH, Taylor MG, Robinet P, Smith JD, Schweitzer J, Sehayek E, Falzarano SM, Magi-Galluzzi C, Klein EA and Ting AH: Dysregulation of cholesterol homeostasis in human prostate cancer through loss of ABCA1. Cancer Res 73: $1211-1218,2013$

17. Argmann CA, Edwards JY, Sawyez CG, O'Neil CH, Hegele RA, Pickering JG and Huff MW: Regulation of macrophage cholesterol efflux through hydroxymethylglutaryl-CoA reductase inhibition: A role for RhoA in ABCA1-mediated cholesterol efflux. J Biol Chem 280: 22212-22221, 2005.

18. Miller T, Yang F, Wise CE, Meng F, Priester S, Munshi MK, Guerrier M, Dostal DE and Glaser SS: Simvastatin stimulates apoptosis in cholangiocarcinoma by inhibition of Rac1 activity. Dig Liver Dis 43: 395-403, 2011.
19. Kamigaki M, Sasaki T, Serikawa M, Inoue M, Kobayashi K, Itsuki H, Minami T, Yukutake M, Okazaki A, Ishigaki T, et al: Statins induce apoptosis and inhibit proliferation in cholangiocarcinoma cells. Int J Oncol 39: 561-568, 2011.

20. Lee J, Hong EM, Jang JA, Park SW, Koh DH, Choi MH, Jang HJ and Kae SH: Simvastatin induces apoposis and suppresses insulin-like growth factor 1 receptor in bile duct cancer cells. Gut Liver 10: 310-317, 2016.

21. Sun Y, Sukumaran P, Varma A, Derry S, Sahmoun AE and Singh B: Cholesterol-induced activation of TRPM7 regulate cell proliferation, migration, and viability of human prostate cells. Biochimica Biophys Acta 1843: 1839-1850, 2014.

22. Yanae M, Tsubaki M, Satou T, Itoh T, Iman M, Yamazoe Y and Nishida S: Statin-induced apoptosis via the suppression of ERK1/2 and Akt activation by inhibition of the geranylgeranyl-pyrophosphate biosynthesis in glioblastoma. J Exp Clin Cancer Res 30: 74, 2011.

23. Lyu J, Imachi H, Iwama H, Zhang $H$ and Murao K: Insulin-like growth factor 1 regulates the expression of ATP-binding cassette Transporter A1 in pancreatic beta cells. Horm Metab Res 48: 338-344, 2016.

24. Dong F, Mo Z, Eid W, Courtney KC and Zha X: Akt Inhibition promotes ABCA1-mediated cholesterol efflux to ApoA-I through suppressing mTORC1. PLoS One 9: e113789 2014.

25. Sripa B, Leungwattanawanit $S$, Nitta $T$, Wongkham $C$, Bhudhisawasdi V, Puapairoj A, Sripa C and Miwa M: Establishment and characterization of an opisthorchiasis-associated cholangiocarcinoma cell line (KKU-100). World J Gastroenterol 11: 3392-3397, 2005.

26. Sirisinha S, Tengchaisri T, Boonpucknavig S, Prempracha N, Ratanarapee S and Pausawasdi A: Establishment and characterization of a cholangiocarcinoma cell line from a thai patient with intrahepatic bile duct cancer. Asian Pac J Allergy Immunol 9: 153-157, 1991.

27. Rattanasinganchan $\mathrm{P}$, Leelawat $\mathrm{K}$, Treepongkaruna SA, Tocharoentanaphol C, Subwongcharoen S, Suthiphongchai T and Tohtong R: Establishment and characterization of a cholangiocarcinoma cell line (RMCCA-1) from a thai patient. World J Gastroenterol 12: 6500-6506, 2006.

28. Sankaranarayanan S, Kellner-Weibel G, de la Llera-Moya M, Phillips MC, Asztalos BF, Bittman R and Rothblat GH: A sensitive assay for ABCA1-mediated cholesterol efflux using BODIPY-cholesterol. J Lipid Res 52: 2332-2340, 2011.

29. Dos Santos CR, Domingues G, Matias I, Matos J, Fonseca I, de Almeida JM and Dias S: LDL-cholesterol signaling induces breast cancer proliferation and invasion. Lipids Health Dis 13: 16, 2014.

30. Pussinen PJ, Karten B, Wintersperger A, Reicher H, McLean M, Malle E and Sattler W: The human breast carcinoma cell line HBL-100 acquires exogenous cholesterol from high-density lipoprotein via CLA-1 (CD-36 and LIMPII analogous 1)-mediated selective cholesteryl ester uptake. Biochem J 349: 559-566, 2000.

31. Lim SC, Parajuli KR, Duong HQ, Choi JE and Han SI: Cholesterol induces autophagic and apoptotic death in gastric carcinoma cells. Int J Oncol 44: 805-811, 2014.

32. Huang YN, Lin CI, Liao H, Liu CY, Chen YH, Chiu WC and Lin SH: Cholesterol overload induces apoptosis in SH-SY5Y human neuroblastoma cells through the up regulation of flotillin-2 in the lipid raft and the activation of BDNF/Trkb signaling. Neuroscience 328: 201-209, 2016.

33. Yao PM and Tabas I: Free cholesterol loading of macrophages induces apoptosis involving the fas pathway. J Biol Chem 275: 23807-23813, 2000.

34. Lin CJ, Liao WC, Chen YA, Lin HJ, Feng CL, Lin CL, Lin YJ, Kao MC, Huang MZ, Lai CH and Kao CH: Statin therapy is associated with reduced risk of peptic ulcer disease in the taiwanese population. Front Pharmacol 8: 210, 2017.

35. Wang T, Seah S, Loh X, Chan CW, Hartman M, Goh BC and Lee SC: Simvastatin-induced breast cancer cell death and deactivation of PI3K/Akt and MAPK/ERK signalling are reversed by metabolic products of the mevalonate pathway. Oncotarget 7: 2532-2544, 2016.

36. Istvan ES and Deisenhofer J: Structural mechanism for statin inhibition of HMG-CoA reductase. Science 292: 1160-1164, 2001.

37. Niesor EJ, Schwartz GG, Perez A, Stauffer A, Durrwell A, Bucklar-Suchan G, Benghozi R, Abt $M$ and Kallend D: Statin-induced decrease in ATP-binding cassette transporter A1 expression via microRNA33 induction may counteract cholesterol efflux to high-density lipoprotein. Cardiovasc Drugs Ther 29: 7-14, 2015. 
38. Sone H, Shimano H, Shu M, Nakakuki M, Takahashi A, Sakai M, Sakamoto Y, Yokoo T, Matsuzaka K, Okazaki H, et al: Statins downregulate ATP-binding-cassette transporter A1 gene expression in macrophages. Biochem Biophys Res Commun 316: 790-794, 2004.

39. Wong J, Quinn CM, Gelissen IC, Jessup W and Brown AJ: The effect of statins on ABCA1 and ABCG1 expression in human macrophages is influenced by cellular cholesterol levels and extent of differentiation. Atherosclerosis 196: 180-189, 2008.

40. Ando H, Tsuruoka S, Yamamoto H, Takamura T, Kaneko S and Fujimura A: Effects of pravastatin on the expression of ATP-binding cassette transporter A1. J Pharmacol Exp Ther 311: 420-425, 2004.

41. Ogunwobi OO and Beales IL: Statins inhibit proliferation and induce apoptosis in Barrett's esophageal adenocarcinoma cells. Am J Gastroenterol 103: 825-837, 2008.

42. Nonaka M, Uota S, Saitoh Y, Takahashi M, Sugimoto H, Amet T, Arai A, Miura O, Yamamoto N and Yamaoka S: Role for protein geranylgeranylation in adult T-cell leukemia cell survival. Exp Cell Res 315: 141-150, 2009.

43. Neufeld EB, Stonik JA, Demosky SJ Jr, Knapper CL, Combs CA, Cooney A, Comly M, Dwyer N, Blanchette-Mackie J, Remaley AT, et al: The ABCA1 transporter modulates late endocytic trafficking: Insights from the correction of the genetic defect in Tangier disease. J Biol Chem 279: 15571-15578, 2004.

44. Neufeld EB, O'Brien K, Walts AD, Stonik JA, Malide D, Combs CA and Remaley AT: The human ABCG1 transporter mobilizes plasma membrane and late endosomal non-sphingomyelin-associated-cholesterol for efflux and esterification. Biology (Basel) 3: 866-891, 2014.

45. Wang J, Mitsche MA, Lütjohann D, Cohen JC, Xie XS and Hobbs HH: Relative roles of ABCG5/ABCG8 in liver and intestine. J Lipid Res 56: 319-330, 2015.
46. Ramirez CM, Davalos A, Goedeke L, Salerno AG, Warrier N, Cirera-Salinas D, Suárez Y and Fernández-Hernando C: MicroRNA-758 regulates cholesterol efflux through posttranscriptional repression of ATP-binding cassette transporter A1. Arterioscler Thromb Vas Biol 31: 2707-2714, 2011.

47. Genvigir FD, Rodrigues AC, Cerda A, Hirata MH, Curi R and Hirata RD: ABCA1 and ABCG1 expressions are regulated by statins and ezetimibe in Caco-2 cells. Drug Metab Drug Interact 26: 33-36, 2011

48. Janowski BA, Willy PJ, Devi TR, Falck JR and Mangelsdorf DJ: An oxysterol signalling pathway mediated by the nuclear receptor LXR alpha. Nature 383: 728-731, 1996.

49. Beyea MM, Heslop CL, Sawyez CG, Edwards JY, Markle JG, Hegele RA and Huff MW: Selective up-regulation of LXR-regulated genes ABCA1, ABCG1, and APOE in macrophages through increased endogenous synthesis of 24(S),25-epoxycholesterol. J Biol Chem 282: 5207-5216, 2007.

50. Wilson JM, Kunnimalaiyaan S, Kunnimalaiyaan $M$ and Gamblin TC: Inhibition of the AKT pathway in cholangiocarcinoma by MK2206 reduces cellular viability via induction of apoptosis. Cancer Cell Int 15: 13, 2015.

51. Mistafa $\mathrm{O}$ and Stenius U: Statins inhibit Akt/PKB signaling via P2X7 receptor in pancreatic cancer cells. Biochem Pharmacol 78: 1115-1126, 2009.

52. Miraglia E, Högberg J and Stenius U: Statins exhibit anticancer effects through modifications of the pAkt signaling pathway. Int J Oncol 40: 867-875, 2012.

This work is licensed under a Creative Commons Attribution-NonCommercial-NoDerivatives 4.0 International (CC BY-NC-ND 4.0) License. 